\title{
Educação Popular e Saúde e democracia no Brasil
}

\author{
Popular Education and Health and democracy in Brazil
}

Educación Popular y Salud y democracia en Brasil

Maria do Socorro de Souza ${ }^{(a)}$

O artigo "Educação Popular, Saúde e democracia no Brasil" chega em um momento oportuno onde questões relativas a sua construção e efetivação precisam ser aprofundadas no contexto dos 25 anos do SUS e redimensionadas à luz das manifestações populares que ocorrem no país.

Essa reflexão exige resgatar o pacto pela democracia e pela cidadania que a sociedade brasileira se propôs a construir nesses últimos 25 anos. Não conseguimos construir o socialismo brasileiro, porém um caminho que fez do Brasil uma das maiores democracias da América Latina, forjada na luta política protagonizada por setores progressistas da nossa sociedade.

Derrubamos a ditadura militar, restabelecemos a ordem e os espaços para o exercício da democracia representativa. Conseguimos - a partir do chão das fábricas, das praças públicas, dos morros, dos bairros, das comunidades do campo e da floresta - construir uma cultura política, tendo por base a práxis dos movimentos sociais, que emergem questionando as formas clássicas de organização e participação por meio apenas dos partidos políticos e do movimento sindical, cuja centralidade da luta política são os conflitos de classe, determinados pela relação capital-trabalho.

Os novos movimentos sociais trazem para o centro do debate político os conflitos e tensões do cotidiano, fundadas na propriedade privada, desigualdades, explorações, exclusões, subvertendo comportamentos, crenças e valores morais e comportamentais, derrubando tabus, muros e cercas. Apresentam uma pauta que defende um modelo de sociedade onde os Direitos Humanos e as mudanças nas relações sociais são a primazia. Apostam na autonomia e na capacidade crítica dos sujeitos de transformarem a sua inserção social. Essa forma de pensar e atuar no mundo dá origem a uma nova pedagogia, uma nova forma de educar para a democracia e a cidadania: a Educação Popular.

Quando o SUS foi concebido, a expectativa era garantir saúde pública, integral e de qualidade para todo cidadão brasileiro. Um sistema que ordenaria as necessidades sociais básicas da população, porque preconizava uma concepção ampliada de saúde, articulando um conjunto de políticas sociais provedoras do bem-estar, como educação, emprego, renda, moradia, saneamento, cultura, lazer e realização da reforma agrária. Ou seja, vida digna como dever do Estado e direito de cidadania para todos.

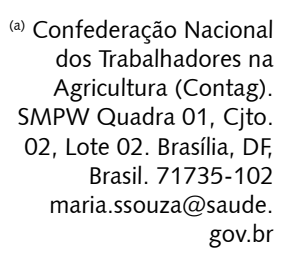

Confederação Nacional dos Trabalhadores na Agricultura (Contag). 2, Lote 02. Brasília, DF, Brasil. 71735-102 gov.br 
Mais recentemente, a participação de setores organizados da sociedade nos espaços públicos foi ampliada nas áreas de políticas públicas sociais e de defesa de direitos humanos. As políticas sociais, entretanto, continuam sendo concebidas como gasto pela equipe econômica do governo, distante de serem consideradas dinamizadoras do desenvolvimento econômico e social do país.

No setor saúde, na instância do controle social nacional, a participação foi ampliada e mantém-se representativa com a entrada de novos atores, os quais têm feito desse lócus um espaço de afirmação de sua identidade, de seus direitos, de suas lutas libertárias, além disso, muitos se mantêm mobilizados de forma autônoma e crítica.

A situação atual exige dos conselheiros um saber técnico, desqualificando ou relativizando o saber político oriundo das classes populares. A composição diversa e diferenciada dos segmentos representados nessa esfera declara que o seu limite pode não estar na legitimidade de sua representação nem no conteúdo político trazido para o espaço público.

A saúde faz interface com o conjunto de necessidades sociais que afetam a vida do povo brasileiro, e parte da solução desse problema está no financiamento adequado e estável, na definição e implementação de planos de cargos salários e carreiras dos profissionais de saúde e num modelo de gestão pública transparente e democrático. Isso exige pacto interfederativo, planejamento e execução de ações intra e intersetoriais. A saúde e seu controle social não podem se setorializar e perder parte do seu significado e sentido político, que é colocar a saúde como um dos pilares da democracia e da cidadania brasileira, visando à construção do Estado de Bem-Estar.

O momento é oportuno. A saúde pode sair da letargia de agenda negativa para uma agenda positiva, a depender dos caminhos que os poderes executivo, legislativo e o controle social trilharem. Entre eles a Mobilização Saúde +10 , que colheu 2,2 milhões de assinaturas nos mais diferentes rincões, propondo que $10 \%$ da receita corrente bruta da União seja destinada à saúde.

Outro exemplo foi a articulação entre trabalhadores e usuários da saúde, que levaram a presidenta Dilma Rousseff a vetar dez pontos da chamada Lei do Ato Médico, que subordinava à tutela médica outros profissionais de saúde igualmente formados e legalmente autorizados a exercer suas funções. Nossas mobilizações também foram determinantes para que as pautas conservadoras, que criminalizavam indígenas, gays, mulheres e usuários de drogas, perdessem forças no Congresso Nacional.

As conferências, conselhos, plenárias de saúde têm rompido, aos poucos, os muros da tecnocracia, da setorização, da intelectualidade inorgânica, do conflito de interesse entre grupos, e ganham as ruas e as praças para ampliar a legitimidade e musculatura política. O debate e posicionamento do controle social acerca de problemas que afetam a saúde do povo brasileiro ganham capilaridade, publicidade e o retorno deve ser para toda a sociedade.

A proposta do Conselho Nacional de Saúde é mobilizar a sociedade e articular as três esferas do controle social por intermédio de uma agenda política que defina as condições para a formulação e implementação de uma política de financiamento público para o SUS, de recursos humanos, de atenção integral, gestão interfederativa e uma política de fortalecimento do controle social.

Dentre esses desafios, nos propomos a construir um plano nacional de Educação Permanente para o Controle Social que assegure os princípios da Educação Popular; uma campanha em defesa do SUS e fortalecimento do controle social; bem como uma nova metodologia para a realização da IV Conferência Nacional de Saúde do Trabalhador e da Trabalhadora, como um ensaio para a realização da XV Conferência Nacional de Saúde, instaurando processos que permitam animar o protagonismo de trabalhadores, legitimando suas organizações e reivindicações.

Esperamos que o Brasil avance na construção de um sistema nacional de participação social que resgate a utopia do pacto pela democracia e cidadania brasileira, e dê sentido às presentes e futuras gerações serem militantes da construção de sistema político e social melhor para o país. 